Original Research Paper

\title{
Developing the Office of Strategic Management as a Tool to Support the Implementation of Balanced Scorecard in Bosowa Corporation
}

\author{
${ }^{1}$ Mashur Razak and ${ }^{2}$ Muhammad Hidayat \\ ${ }^{1}$ Department of Information Technology, STMIK Handayani Makassar, Indonesia \\ ${ }^{2}$ Department of Economics, Sekolah Tinggi Ilmu Ekonomi Nobel Indonesia, Indonesia
}

\author{
Article history \\ Received: 26-07-2016 \\ Revised: 21-11-2016 \\ Accepted: 25-11-2016 \\ Corresponding Author: \\ Mashur Razak \\ Department of Information \\ Technology, STMIK \\ Handayani Makassar, Indonesia \\ Email: mashurrazak@yahoo.com
}

\begin{abstract}
The application of balanced scorecard in the field sometimes still encounter some problems, especially in the integration of functions within the organization where in fact these functions tend to operate in the area of each duty and responsibilities and are not integrated and aligned in achieving organizational goals. The balanced scorecard as a strategic approach tries to provide solutions on how to incorporate the functions that are focused on four business perspectives and how to design strategies linkage in which its application is conducted by applying special division called the Office of Strategic Management (OSM). This study aims at analysing the application of OSM at the company that has implemented the balanced scorecard. It is proved that after the application of the balanced scorecard, the company can grow rapidly and becomes one of the leading companies in Eastern Indonesia.
\end{abstract}

Keywords: Office of Strategic Management, Balanced Scorecard, Organizational Goals

\section{Introduction}

In Indonesia, the Balanced Scorecard has already known well mainly on large companies that open and continue to adapt to developments and market demands. Along with this situation, the Balanced Scorecard has also become one of the topics of interest for the researchers either the researchers led by the company through the function of research and development or the researchers from the academic world who view a very interesting phenomenon related to how to assess and create the company's operations and management in order to create an effective integration between the formulation, implementation and strategic evaluation.

However, there is a fundamental question in the application of the balanced scorecard considering that this approach is a cross-functional approach where the functions consist of four business perspectives in which in the practice, these perspectives are represented by functions that have the departmental duty and responsibility about this cross functional team, Esther (2013) stated that the balanced scorecard provides a mechanism to align the activities and processes of different groups with long term goals of the organization. For example, the financial perspective is represented by accounting and finance departments. The customer perspective is represented by the department of marketing sales and promotion. The production department represents the point of view of internal business process. The perspective of learning and growth is represented by the Department of HRD and GA and the Division of Research and development and IT. Therefore, there is a fundamental question who is responsible, or at least, is a facilitator in the implementation of the balanced scorecard so that the scorecard that has been prepared in such a way can be applied in accordance with the goals and expectations. The importance of balanced scorecard as a tool to support the application has also been submitted by Church and Smith (2007) who conducted research on REA framework as a tool to support the application of the balanced scorecard.

Balanced Scorecard is created from a basic idea about the number of organizations that fail to execute its strategy. The research of Balanced Scorecard Collaborative (BSC $\mathrm{Col})$ found that the main cause is the linkages between strategy execution, corporate goals and overall company performance. The research results are as follows:

a. $67 \%$ of HR and IT organizations do not align with strategy

b. $85 \%$ of the executive team of the company is less than one hour per month discussing strategy

c. $60 \%$ of companies do not link budgets to strategy 
d. $70 \%$ of the incentive compensations of middle managers are not linked to strategy

It occurs because the tendency of the management has entrusted each division within the company and believed that the management will perform each function of the duties and responsibilities so that unconsciously the gap between corporate objectives and departmental execution occurred due to the lack of linkage between the formulation and implementation of the strategy.

Kaplan and Norton (2005b) in the journal of Harvard Business Review (HBR) related to strategic alignment write a review and they start their writing with a question "Why is there such a persistent gap between ambition and performance?". After that, they answer the question by providing the following description.

The gap arises, we believe, from a disconnection in most companies between strategy formulation and strategy execution. Our research reveals that, on average, $95 \%$ of a company's employees are unaware of, or do not understand, its strategy. If the employees who are closest to customers and who operate processes that create value are unaware of the strategy, they surely cannot help the organization implement it effectively.

It does not have to be like this. For the past 15 years, we have studied companies that have achieved performance breakthroughs by adopting the Balanced Scorecard and its associated tools to help them better communicate strategy to their employees and to guide and monitor the execution of that strategy about the organization or company that have aplicate the Balanced Scorecrad we could find them at https://balancedscorecard.org/Resources/About-the-

Balanced-Scorecard/Balanced-Scorecard-Adopters.

In line with the above statement, in the context of existing companies in Indonesia, there are also such tendencies. Many employees do not understand the strategy that is owned by the company. Moreover, many of them do not understand the meaning of the vision and mission owned by the company where they worked. This problem is compounded by the departmental ego which tends to run itself alone according to the interpretation of the department without considering corporate strategy.

Based on the various problems stated above, the balanced scorecard tries to give a solution of how to integrate the functions that are focused on four business perspectives. In addition, the balanced scorecard devises linkage strategies in which its application is conducted by applying the special division called the Office of Strategic Management (OSM). The successful of implementation of the OSM is expressed by Kaplan and Norton as follows.

Some companies, of course, have achieved better and longer-lasting improvements than others. The organizations that have managed to sustain their strategy focus have typically established a new unit at the corporate level to oversee all strategy related activities, an Office of Strategy Management (OSM), as we call it.

Based on the above description, today many organizations or companies have formed a part of the organization called OSM that can help to conduct the alignment between the management process and the strategy. With the existence of OSM, organization or company will have an executive level that focuses on cross-functional business processes. It is required to execute strategy, maintain the benefit, execute permanent strategy and maintain competence in the organization. The organizations that have OSM consist of the Chrysler, US Army, Crown Castle and Canadian Blood Services.

Referring to the study conducted in Indonesia, it should also be informed that some companies in Indonesia have implemented the Balanced Scorecard as well as forming OSM unit with good performance results, namely PT. Ethica Industri, PT Garuda Indonesia and PT. Unilever Indonesia. PT. Ethica Industri has been established on 30 November 1946 and currently, the company demonstrated the ability to continue to exist in the competition even showed the increasingly rapid development after applying the Balanced Scorecard (Wisnu, 2010). The same thing is also indicated in the application of Balanced Scorecard at PT Garuda Indonesia. This state-owned was formally established as a state company in 1956 and currently PT Garuda Indonesia has implemented the Balanced Scorecard and has been able to align the company with the airlines of other world class (Kabarpajak, 2013). Another Indonesia's leading company that has implemented the Balanced Scorecard is PT. Unilever Indonesia. The Balanced Scorecard in this company has been carried out since 2000. It is noted that PT Unilever is one of the Companies which is successful enough in its performance. It is proved that in 2004 the company could reach a profit growth of $14.8 \%$ from the previous year (Putri, 2011).

From the data above, it shows that the right strategy can deliver the company in achieving the right way.

\section{Literature Review}

\section{The Approach Strategy through the Balanced Scorecard Concept}

The balanced scorecard approach is a strategic management approach that is most comprehensive. This approach was first proposed by Kaplan and Norton (1992) the Harvard Business Review. This approach emphasizes that the strategies developed by the organization must be derived from a complete idea that not only focuses on the result but also consider the process undertaken by the organization. It distinguishes between the balanced scorecard approach and the other approach.

In the balanced scorecard approach, a balanced assessment is required from the business perspective of 
organizations that can generally be divided into four categories namely financial, customer, internal business process and learning and growth. These four business perspectives are interrelated in a sequence of causal interaction with one another and in the context of the balanced scorecard, the balance in the interaction between the four perspectives will determine the success of an organization in the process of achieving the vision and mission of the organization.

\section{The Definition of Balanced Scorecard}

The balanced scorecard since it was first rolled out by Kaplan and Norton (1992) has been able to absorb the attention of practitioners and academics who are very interested in this phenomenal approach. As a strategic approach, the balanced scorecard continuously develops and then it produces the other definitions put forward by experts besides the original definition of the originators. The following are the definitions the balanced scorecard.

Balanced Scorecard according to Kaplan and Norton (1996) is:

"A measurement and management system view a business unit performance from 4 perspectives: (1) Financial; (2) Customers; (3) Internal Business Process; and (4) Learning and Growth".

Mc Carthy and Chapman (2008) in www.businessballs.com define the balanced scorecard as follows:

Balanced Scorecard is a strategic planning and management system used to align business activities to the vision statement of an organization. More cynically and in some cases realistically, a balanced scorecard attempts to translate the sometimes vague, pious hope of a company's vision/mission statement into the practicalities of managing the business at every level.

More specific definition of the balanced scorecard in relation to the efforts of improving the organization's internal functions delivered in Investopedia (2013) in http://onsswipe.investopedia.com as follows:

A performance metric is used in strategic management to identify and improve various internal functions and their resulting external outcomes. The balanced scorecard attempts to measure and provide feedback to organizations in order to assist in implementing strategies and objectives.

Atkinson et al. (2004: 445) reveal that Balanced Scorecard is:

A set of performance target and result reflect the organization's performance in meeting its objective relating to its customer, employee, business partners, shareholder and community.

Wijaya (2001: 4) defines the balanced scorecard as follows:

"A strategic management system or more accurately called a Strategic-based responsibility accounting system which outlines the mission and strategy of an organization into operational objectives and performance measures for the four different perspectives namely financial perspective, customer perspective, internal business process perspective and learning and growth perspective".

Based on the above definitions, we can conclude that the balanced scorecard is a strategic management system and the measurement tool for the company's performance performed by analysing carefully the four business perspectives covering financial and nonfinancial aspects. The balanced scorecard will direct the company to conduct an analysis of its strategy not only for the short-term strategy of a company but also longterm strategy on the vision and mission of the company to be able to create a competitive advantage.

Kaplan and Norton (1996) stated "As a management system, the balanced scorecard can be used by the administration to implement various managerial processes that are essential to the organization", namely:

a. The balanced scorecard can be used as a tool to describe the vision, mission and strategy of the company to enable the management in directing the company in achieving its objectives

b. Management can communicate and link strategic objectives and the supporting benchmarks

c. Management can plan, set targets and adjust strategic initiatives

d. Balanced scorecard enhances feedback and strategic learning process

e. The benefit of the application of the balanced scorecard

Akbar (2008) reports that there are several advantages of the implementation of a balanced scorecard for the organization or company as follows:

a. Balanced Scorecard puts strategy, structure and vision of the company's mission to be the centre of attention manager

b. Balanced scorecard emphasizes on a combination of financial and non-financial performance measurement so that management remains focused on overall business processes and provide assurance that the actual operating performance that is run is aligned with the company's long-term strategy and the customer's expectation

c. In practice, the balanced scorecard helps to maintain a balance between building long-term competitive ability and identifying the desire of investors in the financial statements. To perform these activities, the balanced scorecard still uses the traditional performance appraisal. However, the traditional appraiser is viewed from the broader context of a company's competitive strategy to create value in the future, through investments made to customers, suppliers, employees, process technology and innovation 
d. Balanced scorecard enables enterprise managers to assess how their divisions perform value creation today by still considering the interests in the future

e. Balanced scorecard enables managers to assess what they have invested in the progression of human resources, systems and procedures for improvement in the future

Office of Strategic Management (OSM) as a Support Unit of the Balanced Scorecard Applications

Office of Strategic Management (OSM) is a unit which is enabled to act as a facilitator in an organization to ensure that there is a linkage between corporate strategy and strategy execution in the field so that the OSM becomes a centre for coordinating the implementation of the scorecard that has been agreed on the field. In this case, Kaplan and Norton (2005a) describe it as follows:

"...This might appear to be nothing more than a new name for the familiar strategic planning unit. However, the two are quite different. The typical planning function facilitates the annual strategic planning process but takes little or no leadership role in seeing that the strategy gets executed. The companies we studied, however, recognize that effective strategy execution requires communicating corporate strategy; ensuring that enterprise-level plans are translated into the plans of the various units and departments; executing strategic initiatives to deliver on the grand plan; and aligning employees' competency development plans and their personal goals and incentives, with strategic objectives. What's more, they recognize that the company's strategy must be tested and adapted to stay abreast of the changing competition. The OSM becomes the central point for coordinating all these tasks. It does not do all the work, but it facilitates the processes so that strategy execution gets accomplished in an integrated fashion across the enterprise".

Kaplan and Norton (2005a) note that the OSM does not do all the things in the execution of the strategy, but the OSM is a facilitator that directs all units in the organization of work according to the agreed scorecard. Thus, OSM role is in inter-function.

The roles of OSM are highly associated with some processes of strategy:

\section{Scorecard management}

In this function, OSM serves to prepare, design, oversee the implementation of the Balanced Scorecard and report the measurement of the balanced scorecard.

\section{Organization Alignment}

OSM is responsible for ensuring that all operational business units and support align with corporate strategy.
This alignment is implemented using the approaches and management tools that are described in the scorecard sheet so that it is easy to be understood by all components of the organization.

\section{Strategy Reviews}

In this function, OSM creates meeting agenda such as strategy review and learning which can be in the form of weekly review and monthly review. It aims at determining the progress of the implementation of the balanced scorecard in the organization.

\section{Strategic Planning}

OSM is assigned to help CEOs and executive teams in conducting and updating the strategy formulation.

\section{Strategy Communication}

OSM is assigned to communicate and teach strategies to employees. One of the weaknesses of the organization is the presence of ineffective communication even miscommunication that makes incorrect information to the target. Therefore, the problem of communication is a very fundamental thing in implementing the strategy in an organization.

\section{Initiative Management}

In the implementation of the strategy, sometimes some unexpected problems or problems suddenly arise without previous calculations. OSM, in this case, should be able to identify the problem and to be able to take strategic initiatives in addressing this issue. In addition to identifying the possibilities that exist with respect to the implementation of the strategy, OSM also must oversee the strategic management initiatives that have been taken.

\section{Planning/Budgeting}

In terms of planning and budgeting, OSM is assigned to associate between finance, human resources, information technology and marketing strategies. Workforce alignment ensures all objectives, incentives and the link between employee development plans and strategy.

\section{Best Practices Sharing}

OSM must continue to drive organizations to continue to learn to achieve the organization's operations that are effective and efficient. In this case, OSM facilitates the process of identifying the things that need to be improved by implementing organization and conducting sharing best practices for organizations that have been established and can be used as an example of the application of effective and efficient strategies. 
Based on the nine roles stated above, in broad outline OSM can be grouped into several core roles as follows:

\section{Core Roles}

The core roles are Scorecard Management, Organizational Alignment and Strategy reviews.

\section{Desirable/Recommended Roles}

Desirable or recommended roles are strategic planning, communication strategy and initiative management. OSM manages the process of the desirable or recommended roles.

\section{Integrated Roles}

Integrated roles are planning or budgeting, workforce alignment and sharing best practices. These roles are the role of coordination with other departments that is responsible. OSM ensures that the process is completely integrated with the company's strategy. For example:

\section{Planning/budgeting}

This process is coordinated by Chief Financial Officer (CFO), Human Resources Officer (HRO), Chief Information Officer (CIO and Chief Marketing Officer (CMO).

\section{Workforce Alignment}

This process is coordinated by Human Resources Officer (HRO).

\section{Best Practices Sharing}

This process is coordinated by Chief Knowledge Officer (CKO).

Office of Strategic Management Position in Organization or Company

Strategy execution requires continuous organizational change where only the CEO has the authority for it. OSM organizational unit is created to manage strategy execution. Therefore, it would be more effective if OSM has direct access to the CEO. Thus, the OSM must be at independent zone in the organizational structure because the scope for coordination in cross-functional OSM is a great start from the top management, middle management, to lower management.

\section{Working Model for Office of Strategic Management}

OSM does not do all the things in the implementation of the strategy, but it will serve as the division in providing facilities management in implementing the strategy. Working model of OSM as presented by Kaplan and Norton (2005a) is as follows:
From the table above, it shows what phase OSM conducts the process and to what extent OSM involves in these phases. There are two phases in which the involvement of OSM is extremely real. It is in phase 1,2 and 3 in which OSM is fully responsible for implementing the strategy process and the phases 4,5 and 6 where OSM should be involved in this process. In this phase, OSM merely acts as a facilitator.

The research related to the flow of strategic alignment to achieve the performance and value was conducted. This study shows the steps in the application of an integrated corporate strategy although it is not explicitly stated that strategies require the application of a special unit, the workflow application demonstrates that it is important for the organization to have the commitment to focus on its implementation. The importance of focus in balanced scorecard concept is embodied in the form of work unit for corporate of strategic management.

\section{Materials and Methods}

This study was a qualitative study conducted using a Case Study. Data were collected through observation, by performing a systematic observation and recording of the phenomena investigated mainly related to working process on the unit of OSM to facilitate the implementation of the balanced scorecard. Through these observations, the researchers also conducted direct observations on the implementation of coordination meetings facilitated by OSM in the implementation of the monitoring and review of the implementation strategy of the organization in the field. The data were also collected by interviewing management at the corporate level and the level of business unit management and OSM staff. The data were also obtained from the documentation. It was performed by collecting documents related to the process of formulation, implementation and evaluation of strategies, including documentation of the data in the study, especially the documentation of important files and data that support this research. The researchers also conducted Focus Group Discussion (FGD). It was an activity to undertake an in-depth discussion followed by all the interested parties to discuss the data found during the study through data collection that has been conducted before. This forum was also intended to see trends, similarities and differences in the participants in viewing a phenomenon. In this study, FDG involves all parties involved in the implementation of the balanced scorecard and OSM.

\section{Results}

\section{OSM Unit at PT. Bosowa Propertindo}

OSM Unit at Bosowa Corporation is known as the Corporate of the Office of Strategic Management (COSM) which serves as a cross-functional division. The 
main task of COSM is to ensure that the strategy that has been set can be decoded by each business unit owned by the company. In general, the missions of the COSM division at Bosowa Corporation are as follows:

- As a division that facilitates management to strategy formulation

- As an institution that is tasked with ensuring the execution of the strategy at the level of the business that is aligned with corporate strategy through monitoring held regularly in the unit of measure weekly, monthly, semester and annually

- As the institution that is responsible for evaluating the implementation of the strategy in the planning period of business that is generated and will be used as feedback in drafting a strategy for the next business plan period

Based on the vision and the mission above, then the division of COSM in Bosowa is trying to translate what is referred to as a function of management strategies that have been described in the theoretical basis stated above, namely formulation, implementation and evaluation of strategies.

As proposed by Kaplan and Norton (2005a) on the OSM function, then in Bosowa Corporation, COSM is trying to become the division that is responsible for guarding or ensuring that the strategy that has been decided can be applied correctly in accordance with a predetermined plan. This function is to fill the gap between the formulation of strategy at the corporate level and the implementation. This kind of gap is very common in many companies and organizations. Many companies and organizations have a precise strategy formulation and even the formulations often involve consultants who have the capability in drafting the strategy. However, many companies and organizations are not able to execute the strategy because, in the implementation phase, they do not have the institutions or a specific division escorting whether implemented strategies that have been taken is conducted at the level of the field or not. The presence of OSM is to overcome it.

\section{The Function of Strategy Formulation}

As a function of a facilitator in the implementation of strategy formulation, COSM initiated its activities as a facilitator to provide guidance to organizations in interpreting the vision and mission into strategic objectives. To clarify these strategic objectives, the strategic objectives to be achieved by the organization are described in such a way in the perspective of balanced scorecard the financial perspective, customer perspective, internal business process perspective and learning and growth perspective.

COSM further facilitates how the organization conducts advanced formulations associated with the strategic steps that will be implemented for specific objectives by directing management to link the achievement of the objectives of the booster or driver of the desired successful. The goal of this step is that the management will be able to define KPI that is relevant and realistic to be achieved by the organization.

\section{The Function of Strategy Implementation}

The next stage after the strategy formulation stage is the implementation of the strategy. At this stage, COSM serves as a facilitator division that facilitates the leaders to ensure that the strategies that have been formulated in such a way can be implemented properly and precisely according to plan. Therefore, COSM as a facilitator will be updating the strategy implementation by conducting coordination meetings used as a medium of communication and monitoring related to the implementation of the strategy in the field.

Table 1. Office of strategic management roles and responsibility model

\begin{tabular}{ll}
\hline Strategy management process & OSM Role \\
Scorecard management & OSM must run the process \\
Organization alignment & \\
Strategy review & OSM should run the process \\
Strategy planning & \\
Strategy communication & \\
Initiative management & CFO, HRO, CIO, CMO \\
Planning budgeting & HRO \\
Workforce alignment & CKO \\
Best practice sharing & \\
\hline
\end{tabular}

Table 2. Form Identification and Corrective Action (PICA)

\begin{tabular}{|c|c|c|c|c|c|}
\hline Initiative strategy & Problem identification & Corrective action & Target & Due date & PIC \\
\hline $\begin{array}{l}\text { The strategic } \\
\text { objectives that } \\
\text { have been set to } \\
\text { be achieved by } \\
\text { the organization }\end{array}$ & $\begin{array}{l}\text { Obstacles encountered } \\
\text { in the field that makes } \\
\text { the achievement has } \\
\text { not suited for the } \\
\text { objective }\end{array}$ & $\begin{array}{l}\text { Proposed improvement } \\
\text { initiatives to overcome } \\
\text { the obstacles that } \\
\text { occur in the field }\end{array}$ & $\begin{array}{l}\text { Determinants of new } \\
\text { targets after their } \\
\text { problems in the field }\end{array}$ & $\begin{array}{l}\text { The determination of } \\
\text { new deadlines after } \\
\text { considering the problems } \\
\text { in the field }\end{array}$ & $\begin{array}{l}\text { The determination } \\
\text { of responsible } \\
\text { person }\end{array}$ \\
\hline
\end{tabular}


The coordination meetings in Bosowa Corporation are referred to as business review meeting that covers several things as follows:

\section{Weekly review meeting}

Weekly meetings are held to determine the daily operational processes. With the presence of the weekly review, the tendency for the achievement of the business will be able to be detected early. Therefore, if the potential deviation is known, the initiative will soon be performed. In this context, the meeting only does a review and guidance so that all units can do the work and its obligations in accordance with a predetermined plan. Participants of the weekly review are the internal business unit.

\section{Monthly Review}

A monthly review is conducted to understand business achievement for one month. In the context of the meeting, the review is performed thoroughly about the business target that is set forth in the business plan. The thorough discussion of the obstacles and barriers becomes a problem in achieving the goals and proposals for improvement initiatives if problems should become obstacles which have the potential to lead to the failure of predetermined targets.

To organize these problems as well as solutions that can be taken in the meeting, a special form known as PICA form is used (Table 2). Participants of the monthly review are a whole business unit leadership and the Board of Directors.

\section{Semester Review}

Semester review is held as a meeting to evaluate the total toward the achievement of business for six months. The business achievement in this period has been able to give a signal that is strongly associated with a business plan that has been prepared because the period of six months mathematically $50 \%$ of the operational period has been able to describe the achievement of $50 \%$ of the business targets that have been budgeted.

In the semester review, the proposal of the target changes is also planned if the condition of the previous six months has provided an accurate description that the targets that had been set are unrealistic to be achieved. Participants of the semester review are the leadership of the board of directors of the business unit and corporate management board.

\section{Annual Meeting}

The annual meeting is held as a whole evaluation meeting on the achievement of business performance during the period. In this meeting, the final result of the achievement of the business in the current year will be known so that the score of the balanced scorecard for each perspective has been already seen and will be used as a reference in the preparation of the business plan for the following year. Participants of the annual meeting are the leadership of the board of directors of business units and business unit management board of the corporation.

Through this research, the researchers can describe the flow of work processes of COSM at Bosowa Corporation. The first is the process of formulation or planning known as planning cycle, where COSM involvement in this process is to facilitate the leaders in conducting strategy formulation by providing a template, as planning cycle which became a reference guide for the company planning to be implemented. The second is the strategy implementation process of COSM that is responsible to facilitate the implementation of the monitoring of the execution of strategy through meetings coordination that is held regularly, namely the weekly review, monthly review, Quarterly review and semester review in which the results become a reference in making corrections and adjustments required in achieving goals which have been specified. The third is that COSM facilitates the management and provides accurate data on the implementation of strategies that include evaluation of the strategy to be used as a feedback and a basis for developing the future strategy along with reward and punishment that can be taken by management.

Through the results of this study, researchers describe the application of COSM model in Bosowa Corporation as shown in Fig. 1.

The green, yellow and red collor that shown in the Fig. 1 have a meaning as follow; the green is the light that is given by COSM to assess whether the performance is in accordance with the target or not. Yellow is notation that is given by COSM to assess whether the performance is less appropriate for the target or not. Red is notation that is given by COSM to assess whether the performance is not appropriate for the target or not.

The above model is the development of a model of OSM roles and responsibilities presented by Kaplan and Norton (2005a), as shown at Table 1, which recognize the strategy management process consists of nine phases (1) Scorecard management (2) Organization alignment (3) Strategy review (4) Strategy planning (5) strategy communication (6) management initiative (7) planning budgeting (8) Workforce alignment (9) Best practice sharing.

In the model above, the first, the third and the seventh phase are illustrated in COSM processes that are at the corporate level in determining the scorecard management through planning process cycle. The third and the fourth phase are represented in COSM process that works at the level of the business units to carry out review meetings periodically. Communication strategy at the meeting review is also carried out mainly by using the form Problem Identification and Corrective Action (PICA), which is intended to streamline communication especially in terms of the constraints and the problem solving in the implementation of the strategy. 


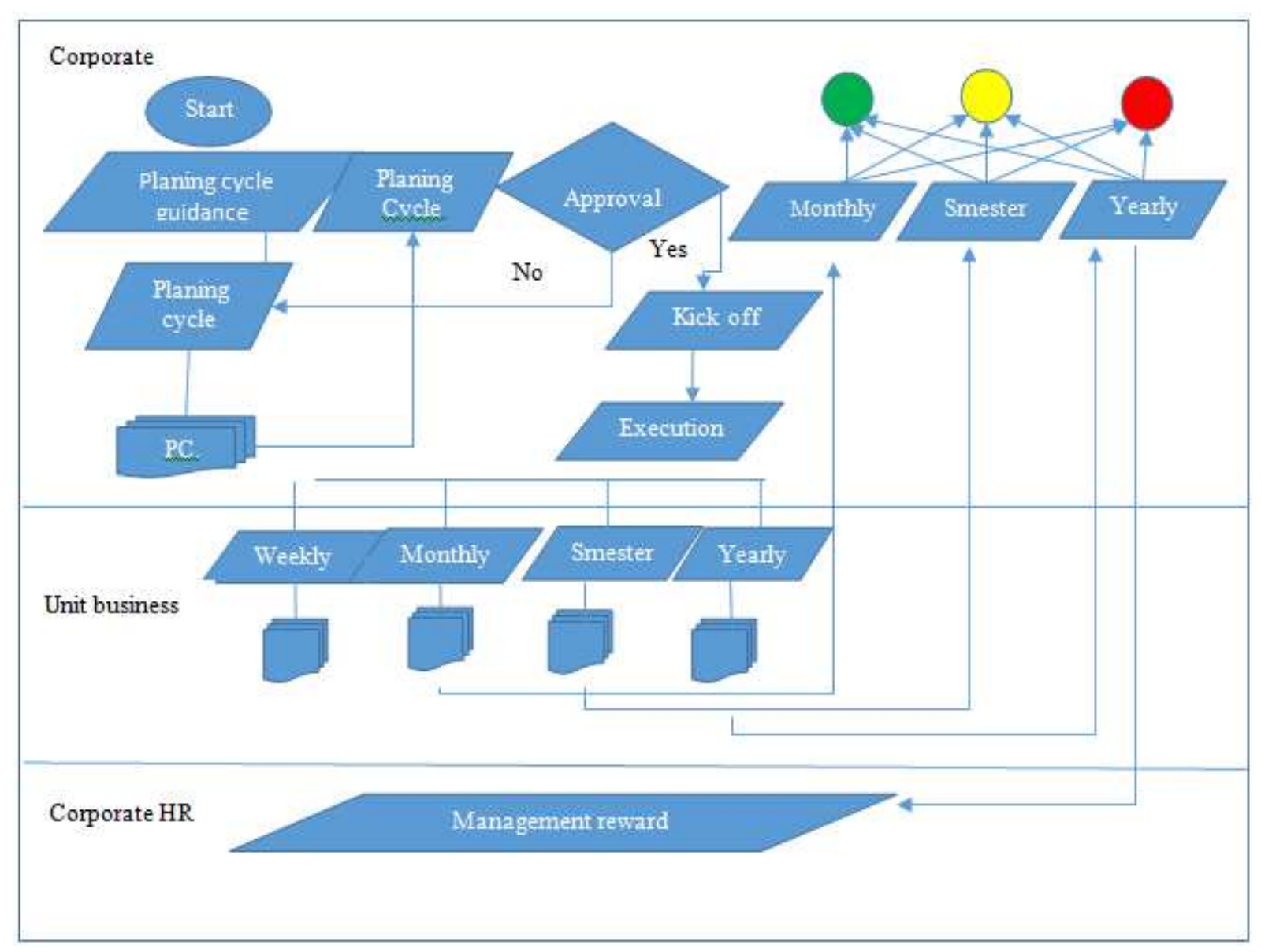

Fig. 1. The flow of working model of CSOM in Bosowa corporation

The eighth and the ninth phase in this model are interpreted through corporate human resources where the results of the evaluation will be a feedback strategy for corporate HR to undertake improvement initiatives as well as to perform the provision of reward and punishment.

\section{The Process of Balanced Scorecard Implementation and the Effectiveness of OSM in Bosowa}

The application of Balanced Scorecard in Bosowa Corporation begins with the implementation of the program of management development in 2007 that creates development document called Bosowa Umbrella Management System (BUMS). This process is accompanied by a management consultant of Transformer Management Service for some period in which in the transformation of this organization there are improvements and changes to the organizational structure comprehensively tailored to organizational goals. Moreover, it is undeniable that there is rationalization new recruitment process to get the resources to ensure that the process of management and organizational processes run smoothly. For this purpose, Bosowa Corporation formed a special unit called the division of Plan Do Check and Action (PDCA) in which the functions and duties are as the independent division that will facilitate the process of the organization in accordance with a predetermined goal. The duties and responsibilities of PDCA are in accordance with the role of OSM delivered by Kaplan and Norton (2005a) which the essence is as a facilitator in, organization and management institutions in the implementation of formulation strategy, implementation strategy and evaluation strategy.

The success of the process is characterized by the application of the balanced scorecard system in 2007 marked by the company's ability to develop its business units. There are 12 business units before 2007 and it can grow to 37 units in 2009 and until now Bosowa Corporation already has 55 business units that are managed in 8 holding area, namely Automotive, Cement, Infrastructure, Financial Services, Media, Property, Agribusiness and mining. The effectiveness of OSM on Bosowa Corporation can be seen from the achievement of scores Balanced Scorecard. Table 3-6 are the example of the calculation of the value of the Balanced Scorecard at PT. Bosowa Property which is a part of Bosowa Corporation. 
Balanced Scorecard assessment results in consecutive at PT Bosowa Propertindo increase from year to year. According to the assessment criteria that apply to the attainment of the Balanced Scorecard at Bosowa Corporation, it can be stated that assessment on PT Bosowa Propertindo BSC in 2013 was 2.71 (3) which was in accordance with the target. Then in 2014, it was 3.29 (3) and it means that there was an increasing number compared with 2013 , but it was still within the range of 3 that is in accordance with the target. The achievement in 2015 was 3.92 (4) in which this achievement exceeds the target. The results above indicate the effectiveness of OSM at Bosowa Propertindo which is also part of Bosowa Corporation.

The determination of Key Performance Indicator (KPI) for each business unit in Bosowa vary between one another. It is in accordance with the Balanced Scorecard concept that the KPI should be prepared in accordance with the type of business for each organization. However, it could be said that the achievement of the score in each business unit in Bosowa show tune data that shows a significant development so that it can develop Bosowa Corporation as a whole.

Table 3. Achievement of BSC score in Bosowa Propertindo in 2013

\begin{tabular}{|c|c|c|c|c|c|c|c|}
\hline \multirow[b]{2}{*}{ No-1 } & \multirow[b]{2}{*}{ Perspectives-2 } & \multirow[b]{2}{*}{ Weight-3 } & & \multicolumn{2}{|l|}{ KPI-4 } & \multicolumn{2}{|c|}{ Score-5 } \\
\hline & & & & B (\%) & $\mathrm{N}$ & $\mathrm{N} \times \mathrm{B}$ & $(3) \times(4)$ \\
\hline \multirow[t]{5}{*}{1} & Financial & $45 \%$ & & 25 & 3 & 0.75 & 0.3375 \\
\hline & & & & 25 & 3 & 0.75 & 0.3375 \\
\hline & & & & 25 & 1 & 0.25 & 0.1125 \\
\hline & & & & 25 & 4 & 1.00 & 0.4500 \\
\hline & & & & 100 & & & 12.3750 \\
\hline \multirow[t]{2}{*}{2} & Customer & $5 \%$ & & 100 & 3 & 3.00 & 0.1500 \\
\hline & & & & 100 & & & 0.1500 \\
\hline \multirow[t]{3}{*}{3} & Internal business proses & $40 \%$ & & 50 & 5 & 2.50 & 1.0000 \\
\hline & & & & 50 & 1 & 0.50 & 0.2000 \\
\hline & & & Total & 100 & & & 1.2000 \\
\hline \multirow[t]{9}{*}{4} & Growth and learning & $10 \%$ & Employee satisfaction & 20 & 2 & 0.40 & 0.0400 \\
\hline & & & The number of employees & & & & \\
\hline & & & who attend training & 20 & 1 & 0.20 & 0.0200 \\
\hline & & & The timing of the training & 20 & & 0.00 & 0.0000 \\
\hline & & & Cost of education and training & 10 & 1 & 0.10 & 0.0100 \\
\hline & & & Availability of information & 10 & 2 & 0.20 & 0.0200 \\
\hline & & & Accuracy of information & 10 & 2 & 0.20 & 0.0200 \\
\hline & & & Speed of information & 10 & 2 & 0.20 & 0.0200 \\
\hline & & & Total & 100 & & & 0.1300 \\
\hline \multicolumn{4}{|c|}{ The total score of balanced scorecard } & & & & 2.7175 \\
\hline
\end{tabular}

Table 4. Achievement of BSC score in Bosowa Propertindo in 2014

\begin{tabular}{|c|c|c|c|c|c|c|c|}
\hline \multirow[b]{2}{*}{ No-1 } & \multirow[b]{2}{*}{ Perspectives-2 } & \multirow[b]{2}{*}{ Weight-3 } & & \multicolumn{2}{|l|}{ KPI-4 } & \multicolumn{2}{|c|}{ Score-5 } \\
\hline & & & & $\mathrm{B}(\%)$ & $\mathrm{N}$ & $\mathrm{N} \times \mathrm{B}$ & $(3) \times(4)$ \\
\hline \multirow[t]{5}{*}{1} & Financial & $45 \%$ & Profitability Index & 25 & 4 & 1.00 & 0.450 \\
\hline & & & Investment return rate & 25 & 3 & 0.75 & 0.3375 \\
\hline & & & Return on Investment (ROI) & 25 & 4 & 1.00 & 0.450 \\
\hline & & & Current Ratio & 25 & 4 & 1.00 & 0.450 \\
\hline & & & Total & 100 & & & 16.875 \\
\hline \multirow[t]{2}{*}{2} & Customer & $5 \%$ & Level of customer satisfaction & 100 & 3 & 3.00 & 0.150 \\
\hline & & & Total & 100 & & & 0.150 \\
\hline \multirow[t]{3}{*}{3} & Internal business proses & $40 \%$ & Innovation ratio & 50 & 5 & 2.50 & 1.000 \\
\hline & & & Production quality & 50 & 1 & 0.50 & 0.200 \\
\hline & & & Total & 100 & & & 1.200 \\
\hline \multirow[t]{8}{*}{4} & Growth and learning & $10 \%$ & Employee satisfaction & 20 & 2 & 0.40 & 0.040 \\
\hline & & & $\begin{array}{l}\text { The number of employees } \\
\text { who attend training }\end{array}$ & 20 & 3 & 0.60 & 0.060 \\
\hline & & & The timing of the training & 20 & & 00.00 & 0.000 \\
\hline & & & Cost of education and training & 10 & 1 & 0.10 & 0.100 \\
\hline & & & Availability of information & 10 & 2 & 0.20 & 0.020 \\
\hline & & & Accuracy of information & 10 & 2 & 0.20 & 0.020 \\
\hline & & & Speed of information & 10 & 2 & 0.20 & 0.020 \\
\hline & & & Total & 100 & & & 0.260 \\
\hline \multicolumn{3}{|c|}{ The total score of balanced scorecard } & & & & & 3.2975 \\
\hline
\end{tabular}


Table 5. Achievement of BSC score in Bosowa Propertindo in 2015

\begin{tabular}{|c|c|c|c|c|c|c|c|}
\hline \multirow[b]{2}{*}{ No-1 } & \multirow[b]{2}{*}{ Perspectives-2 } & \multirow[b]{2}{*}{ Weight-3 } & & \multicolumn{2}{|l|}{ KPI-4 } & \multicolumn{2}{|c|}{ Score-5 } \\
\hline & & & & $\mathrm{B}(\%)$ & $\mathrm{N}$ & $\mathrm{N} \times \mathrm{B}$ & $(3) \times(4)$ \\
\hline \multirow[t]{5}{*}{$\overline{1}$} & Financial & $45 \%$ & Profitability index & 25 & 4 & 1.00 & 0.4500 \\
\hline & & & Investment return rate & 25 & 3 & 0.75 & 0.3375 \\
\hline & & & Return on Investment (ROI) & 25 & 4 & 1.00 & 0.4500 \\
\hline & & & Current ratio & 25 & 4 & 1.00 & 0.4500 \\
\hline & & & Total & 100 & & & 16.8750 \\
\hline \multirow[t]{2}{*}{2} & Customer & $5 \%$ & Level of customer satisfaction & 100 & 3 & 3.00 & 0.1500 \\
\hline & & & Total & 100 & & & 0.1500 \\
\hline \multirow[t]{3}{*}{3} & Internal business proses & $40 \%$ & Innovation ratio & 50 & 5 & 2.50 & 1.0000 \\
\hline & & & Production Quality & 50 & 4 & 2.00 & 0.8000 \\
\hline & & & Total & 100 & & & 1.8000 \\
\hline \multirow[t]{8}{*}{4} & Growth and learning & $10 \%$ & Employee Satisfaction & 20 & 3 & 0.60 & 0.0600 \\
\hline & & & $\begin{array}{l}\text { The number of employees } \\
\text { who attend training }\end{array}$ & 20 & 3 & 0.60 & 0.0600 \\
\hline & & & The timing of the training & 20 & 3 & 0.60 & 0.0600 \\
\hline & & & Cost of education and training & 10 & 4 & 0.40 & 0.0400 \\
\hline & & & Availability of information & 10 & 3 & 0.30 & 0.0300 \\
\hline & & & Accuracy of information & 10 & 2 & 0.20 & 0.0200 \\
\hline & & & Speed of information & 10 & 2 & 0.20 & 0.0200 \\
\hline & & & Total & 100 & & & 0.2900 \\
\hline \multicolumn{3}{|c|}{ Nilai total balanced scorecard } & & & & & 3.9200 \\
\hline
\end{tabular}

Table 6. Assessment criteria

\begin{tabular}{lll}
\hline Score & Descriptive & Presentation \\
\hline 5 & Achievement exceeds the target & $>130 \%$ \\
4 & Achievement is less than the target & $111-130 \%$ \\
3 & Achievement is in accordance with the target & $91-110 \%$ \\
2 & Achievement reaches the minimum target & $80-90 \%$ \\
1 & Achievement is lacking or very far from the target & $<80 \%$ \\
\hline
\end{tabular}

\section{Discussion}

The application of COSM division at Bosowa Corporation can be seen as a model for practical application of the theory in the field. It is an answer that is very helpful to answer a fundamental question that has been growing about how to apply a strategy so that the strategy that had been developed by the company can be conducted operationally considering that in practice divisions in the company or organization tend to have been preoccupied with the task and respective responsibilities. Thus, the system or strategy is forgotten because no system or strategy escorts the system intensively and continuously.

Kaplan and Norton (2005a) assert that the OSM does not do all the things in the execution of the strategy but the OSM is a facilitator that directs all units in the organization of work in accordance with the scorecard that has been agreed and is therefore the role of OSM in inter-function point is escorted through the work procedures that will direct the operational and managerial actors within the corridor of predetermined business planning.

With the presence of COSM in Bosowa Corporation, directly or indirectly, the division will continue to direct the responsible people to be in the commitment to achieve business scorecard because they will continue to be questioned by the COSM division in the media review that has been predetermined periodically.

The presence of periodic review is going to create a culture of its own so it would remind each other seriously and seek to achieve the thing that becomes the responsibility in accordance with the proposed measures, targets and deadlines.

The effectiveness of the formation of COSM Division in Bosowa Corporation looks very significant. It can be seen from the development of Bosowa Corporation since the thorough modernization through Excellent Bosowa Program in 2007 were made and the application of balanced scorecard as a strategy approach has led corporations Bosowa to become a famous company in Eastern Indonesia.

\section{Conclusion}

Through this research, it is known that OSM can be applied effectively in supporting the implementation of the balanced scorecard in a company. The roles and responsibilities of OSM that have been presented by Kaplan and Norton (2005a) 
can be applied by adjusting the needs of the organization or company. Thus, it can be stated that the application of OSM between one company and another company can be different because each company has a different vision, mission and culture.

In other words, OSM could use a different approach and name as well as a different model, but one important thing that needs to be understood is that the basis of the application of OSM is a division whose job is to support and facilitate the management in carrying out the formulation, implementation and evaluation of strategies.

\section{Acknowledgement}

This research was purely done by Mashur Razak \& Muhammad Hidayat and there are no previous studies before, especially research related to the application of the OSM and the Balanced Scorecard at Bosowa Corporation.

\section{Funding Information}

The research was funded by both of researcher personally.

\section{Author's Contributions}

Mashur Razak: Design the reasearc plan, Organizing the research, supervising in writing and collecting supporting literature.

Muhammad Hidayat: Collecting data from the research object and prepare the research analysis in balanced Scorecard Approach.

\section{Ethics}

Research about the office for strategic management (OSM) is still very limited so that further studies of this field will be able to contribute more to the development of management science especially in the field of strategic management science.

\section{References}

Esther, A., 2013. Strategic decision making, balance scorecard profitability: Issues and challenges. Int. J. Account. Res., 1: 20-31.

Atkinson, A.A, R.D. Banker, R.S. Kaplan and S.M. Young, 2004. Management Accounting. 4th Edn., Pearson Prentice Hall, Upper Saddle River, ISBN-10: 0130082171, pp: 598.

Putri, A., 2011 Unilever menerapkan balanced scorecard.
Church, K.S. and R.E. Smith, 2007. An extension of the REA Framework to support balanced scorecard information requirements. J. Inform. Syst., 21: 1-25. DOI: $10.2308 /$ jis.2007.21.1.1

Wisnu, D., 2010. Balanced scorecard dan analytical hierarchy process. www.wisnudewobroto.com

Kabarpajak, 2013. Rancangan balanced scorecard PT. garuda Indonesia. www.kabarpajak.com

Kaplan, R.S. and D.P. Norton, 1992. The Balanced scorecard-measures that drive Performance. Harvard Bus. Rev.

Kaplan, R.S. and D.P. Norton, 1996. Using the Balanced scorecard as a strategic management system. Harvard Bus. Rev.

Kaplan, R.S. and D.P. Norton, 2005a. Creating the Office of Strategy Management. Working paper. Balanced Scorecard Collaborative.

Kaplan, R.S. and D.P. Norton, 2005b. Focus Your Organization On Strategy Focusing Your Organization on Strategy-with the Balanced Scorecard. 2nd Edn., Harvard Business School Publishing, ISBN-10: 9990933529, pp: 75.

Akbar, R.J., 2005. Measuring the Performance of Rural Banks through a Balanced Scorecard Approach. Pasca Sarjana Ubhara Raya. Jakarta

Wijaya, T.A., 2001. Understanding the Balanced Scorecard concept. Harvarindo, Jakarta.

Mc Carthy and Chapman, 2008. The Balances Scorcard Devinition. www.businessballs.com. diunduh Juni 2016

Investopedia, 2013. Balanced Scorecard Definition. http://onsswipe.investopedia.com 